\title{
Probabilistic Risk Assessment in Medium Scale for Rainfall-Induced Earthflows: Catakli Catchment Area (Cayeli, Rize, Turkey)
}

\author{
H. A. Nefeslioglu1 ${ }^{1}$ and C. Gokceoglu² \\ ${ }^{1}$ General Directorate of Mineral Research and Exploration, Department of Geological Research, \\ Balgat, 06520 Ankara, Turkey \\ ${ }^{2}$ Hacettepe University, Department of Geological Engineering, Applied Geology Division, \\ Beytepe, 06800 Ankara, Turkey
}

Correspondence should be addressed to H. A. Nefeslioglu, hanefeslioglu@mta.gov.tr

Received 23 October 2010; Accepted 8 January 2011

Academic Editor: Ming Li

Copyright (C) 2011 H. A. Nefeslioglu and C. Gokceoglu. This is an open access article distributed under the Creative Commons Attribution License, which permits unrestricted use, distribution, and reproduction in any medium, provided the original work is properly cited.

The aim of the present study is to introduce a probabilistic approach to determine the components of the risk evaluation for rainfall-induced earthflows in medium scale. The Catakli catchment area (Cayeli, Rize, Turkey) was selected as the application site of this study. The investigations were performed in four different stages: (i) evaluation of the conditioning factors, (ii) calculation of the probability of spatial occurrence, (iii) calculation of the probability of the temporal occurrence, and (iv) evaluation of the consequent risk. For the purpose, some basic concepts such as "Risk Cube", "Risk Plane", and "Risk Vector" were defined. Additionally, in order to assign the vulnerability to the terrain units being studied in medium scale, a new more robust and more objective equation was proposed. As a result, considering the concrete type of roads in the catchment area, the economic risks were estimated as $3.6 \times 10^{6} €$-in case the failures occur on the terrain units including element at risk, and $12.3 \times 10^{6} €$-in case the risks arise from surrounding terrain units. The risk assessments performed in medium scale considering the technique proposed in the present study will supply substantial economic contributions to the mitigation planning studies in the region.

\section{Introduction}

Mass movements constitute one of the major geologic hazards on the Planet Earth. Basically, the term "mass movement" could be defined as the down slope movement of the earth material under the control of the gravitational forces. This simply defined earth surface process, however, causes considerable direct and indirect economic losses and deathly casualties in the world every year. The annual economic deficits reach up to approximately 4 billion US dollars and nearly 1000 people per year lose their lives in the world due to 
mass movements [1]. Additionally, ISDR [2] declares the portion of deathly casualties due to landslides in natural hazards as $1.3 \%$ in the world. In Turkey, this ratio increased approximately ten times greater than the statistics given for all over the world. Considering the structural losses due to mass movements in Turkey, landslides constitute the second important natural hazard with a portion of $15 \%$ after earthquakes [3]. In order to decrease direct and/or indirect casualties due to mass movements, land use planning studies in medium or regional scales have a crucial importance. One of the main requirements of such studies is the mapping of areal distribution of the past and recent landslides in the region. However, evaluation of these movements only is not enough for land use planning studies. In addition to this mapping procedure, determination of possible future failure locations and expected losses is also necessary for realistic planning applications. For this purpose, landslide susceptibility - the probability of spatial occurrence and hazard-and the probability of temporal occurrence evaluations have been performed by engineering geologists and geomorphologists for many years. By using the hazard values, risk evaluations for the elements at risk threatened by the responsible hazard could also be assessed. Even though the algorithms for landslide hazard and risk evaluations are able to be defined exactly, they involve highly complex processes in application. Uncertainties in calculation of runout distances, transformation of susceptibility values to hazards rates, and determination of vulnerability functions for the elements at risk constitute the main limitations for landslide hazard and risk studies. IUGS [4] notes the main restrictions as follows: inherent uncertainty of the input parameters, different considerations for the same problem due to different approaches, changing of the results due to data revision, inability to verify the produced maps, and using the methodologies not widely accepted. Van Westen et al. [5] stated that the quantitative landslide risk evaluations are able to be performed for site specific purposes and/or linear engineering structures such as pipelines and highways. However, the authors also emphasized that there still have been lots of uncertainties in risk evaluation, and for this reason the results of the recent researches on landslide risk assessments in medium and/or regional scales seem still inapplicable in land use planning studies. In very recent literature, different types (inventory, susceptibility, hazard, and risk) and levels of zoning (preliminary, intermediate, and advanced) are proposed considering the mapping scale [6-8]. According to Fell et al. [7], landslide hazard mapping in medium to small $(1: 25,000$ to $1: 250,000)$ scale with intermediate zoning level (statistical analyses) for advisory purposes may be applicable. This recommendation is given as applicable for both landslide hazard mapping and risk zoning in large to medium $(1: 5000$ to $1: 25,000)$ scale by the same authors. The limitations mentioned here are mostly controlled with the spatial data resolution itself. With the decreasing of the spatial resolution hypothetic assumptions increase, the uncertainties arise, and therefore, probabilistic approaches are introduced. On the other hand, depending on the increment of the spatial resolution the uncertainties relatively decrease; it is relatively close to the actual physical conditions, and therefore, deterministic approaches become applicable. Probabilistic approaches are able to be evaluated effectively in medium- and regional-scaled planning studies while deterministic methods allow performing site-specific applications in high scales. The aim of the present study is to introduce a probabilistic approach to determine the components of the risk evaluation and to map the consequent risk in medium scale $(1: 25,000)$ in a rainfall-induced earthflow prone area. For the purpose, the Catakli catchment area locating in the East Black Sea Region, at the east of Rize province and Cayeli district, was selected as the application site of this study (Figure 1). The investigations were performed in four different stages: (i) evaluation of the conditioning factors, (ii) calculation of the probability of spatial 


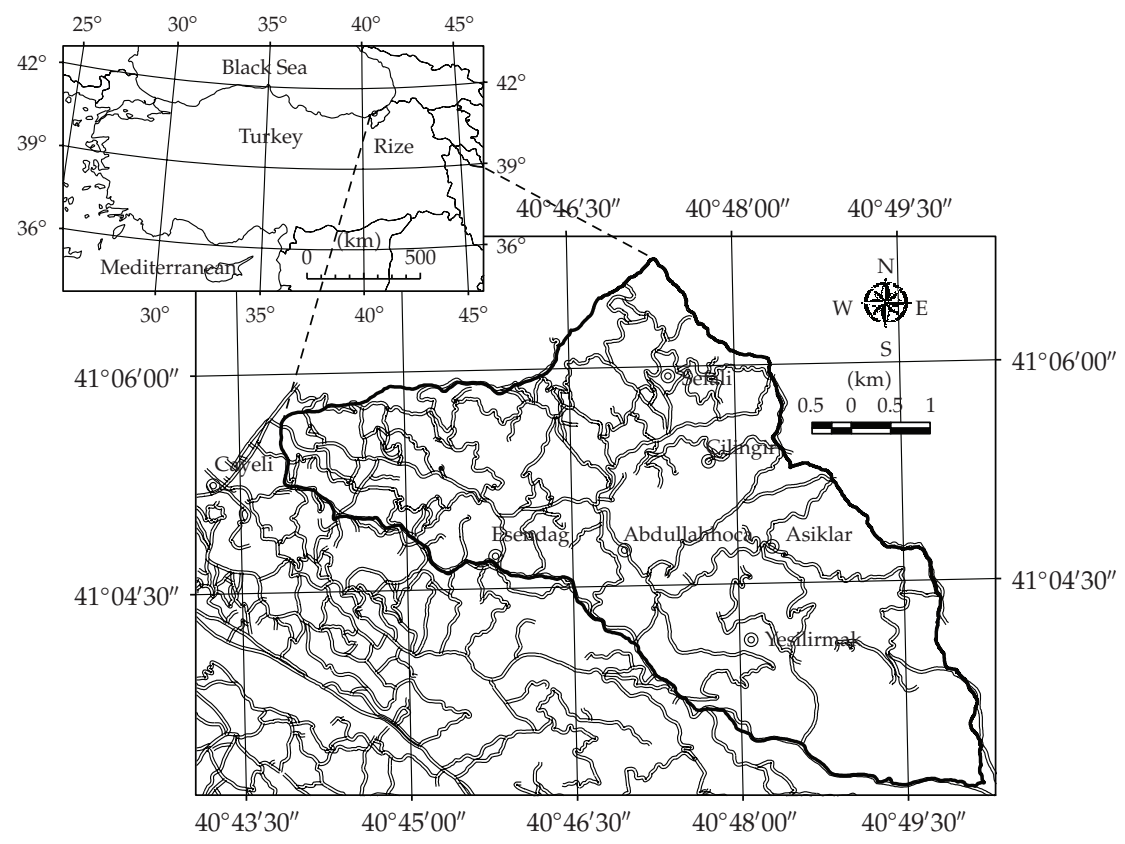

Figure 1: Location map of the Catakli catchment area.

occurrence, (iii) calculation of the probability of the temporal occurrence, and (iv) evaluation of the consequent risk.

\section{Rainfall-Induced Earthflows}

The region East Black Sea in which the Catakli catchment area takes place received the most rain in Turkey. According to the data published by DMI [9], annual mean precipitation in the period of 1971 and 2000 is given as about $2189 \mathrm{~mm}$. Depending on the climatic characteristics plus geological and geomorphologic features, rainfall-induced earthflows accompanied by flood events frequently occur in the region. Tarhan [10] reported that total 252 deathly casualties and 2585 structural destructions happened in the region since 1970. Can et al. [11] noted that total 121 earthflows were triggered by the meteorological event happened on July 23rd in 2002 in the Islahiye catchment area located near west of the Catakli catchment area. The authors also stated that the earthflows caused 17 losses of lives and devastation of 4 houses. In addition, Dag et al. [12] mentioned that some earthflows also occurred around the Cayeli district during the same meteorological event and caused substantial economic deficits and losses of lives in the region. Nefeslioglu [13] mapped and dated total 251 earthflows between the years of 1955 and 2007 in the Buyukkoy catchment area also located near southwest of the Catakli catchment area. The frequency of the earthflows is very low before 1990; however, this value abruptly increases after 1990; 3.2\% of the failures occurred before 1990 while $57 \%$ of those happened only in 2002 in the region [13]. According to Nefeslioglu [13], anthropogenic disturbance which begun early in the 1970s and still continues might be the possible reason for this peculiarity. The earthflows observed in the Catakli catchment area mapped during the field studies performed by the Geological Research Department of General Directorate of Mineral Research and Exploration (MTA) in 2003. 


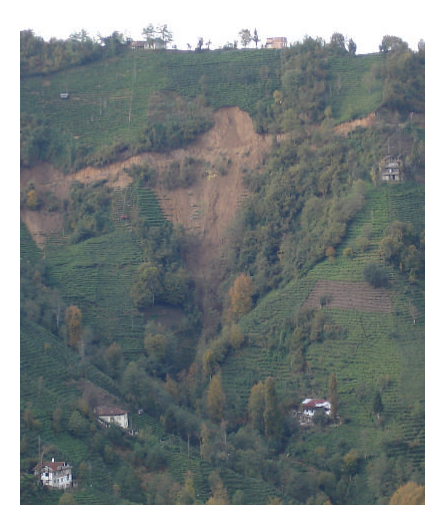

(a)

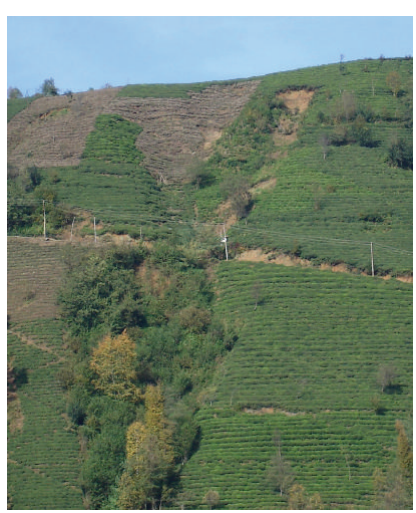

(b)

Figure 2: Typical views of the earthflows occurred in the region; (a) fresh, and (b) a few years old.

The landslide research team of the department mapped total 101 earthflows mostly triggered by the meteorological event happened on July 23rd in 2002 [14]. General characteristics of these shallow mass movements are being of small-size and short-lived (Figure 2). Since the failures are small-size and short-lived, Nefeslioglu [13] mentioned that mapping of these movements in medium scale is highly challenging. According to the research performed by the author, the mean depletion zone area for these failures is about $500 \mathrm{~m}^{2}$, and the mean $2000 \mathrm{~m}^{3}$ residual soil material exhibits mean $80 \mathrm{~m}$ runout distance in the region. In the present study, as suggested by Nefeslioglu [13], the earthflows in the Catakli catchment area were represented using individual points corresponding to the scarps of the movements on the map (Figure 3).

\section{Conditioning Factors}

The earthflows observed in the catchment area occurred in residual soils which decomposed from different volcanic rocks cropped out in the region. This undifferentiated volcanic complex is composed of Tertiary aged andesite, basalt lava, and pyroclastics $[15,16]$. The intensities of the movements are primarily controlled by the thickness and material properties of the residual layers (Figure 4). Obviously, the thickness and material properties of residual soils are directly influenced by the host rockmass discontinuities, topography, and climate [17]. However, mapping of the thickness and material properties of residual layers in regional or medium scale is unrealistic particularly in such regions. Furthermore, unfortunately the material properties and in situ water conditions of residual soils are commonly able to be defined only qualitatively in stability analyses performing in large-scales [17]. Therefore, the prediction performances of conventional stability analyses are usually obtained as very low in residual soils [18]. As a consequence, as mentioned by Nefeslioglu [13], instead of establishing large-scaled stability analyses, it is more realistic to perform probabilistic applications such as susceptibility evaluations in medium scale to assess natural slope stability conditions in residual soils.

The parameters topographic altitude, slope gradient, profile slope curvature, and plan slope curvature were also investigated in the present study. To derive these topographic factors, a grid-based digital elevation model having a spatial resolution 


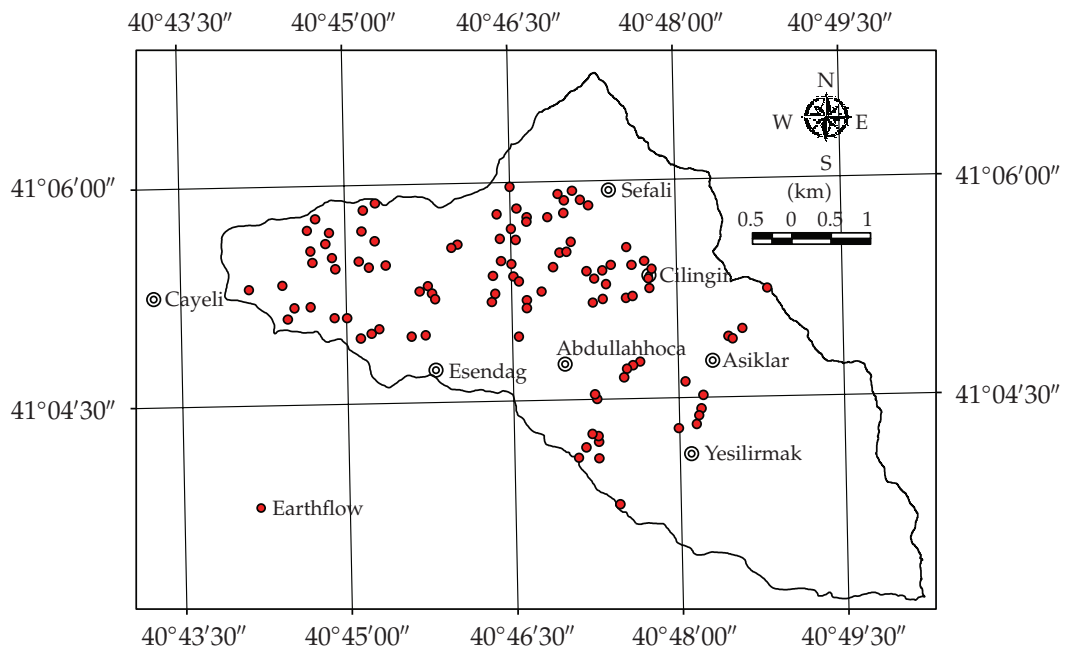

Figure 3: Earthflow inventory of the catchment [14].

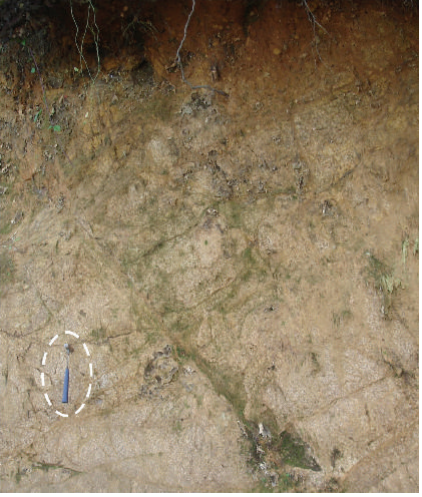

(a)

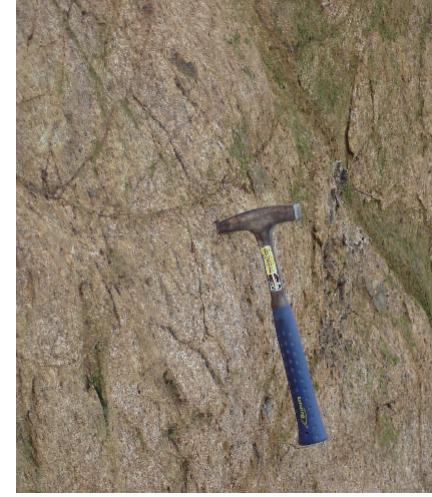

(b)

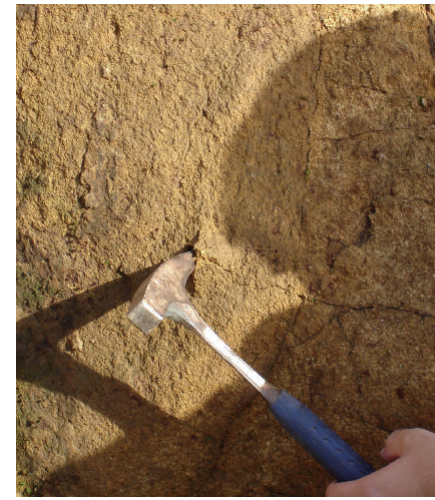

(c)

Figure 4: Typical residual soil profile observed in the catchment: (a) a complete profile, (b) and (c) close views from completely weathered and weak-saprolite zones of the profiles.

of $10 \mathrm{~m} \times 10 \mathrm{~m}\left(100 \mathrm{~m}^{2}\right)$ was constructed in ArcView 3.2 GIS environment using $10 \mathrm{~m}$ altitude contours of the $1: 25,000$ scaled topographic maps. The descriptive statistics for the parameters are given in Table 1. According to these descriptive evaluations, the topographic altitude values in the catchment vary between $7 \mathrm{~m}$ and $1212 \mathrm{~m}$. This range is obtained as $78 \mathrm{~m}$ and $450 \mathrm{~m}$ on the terrain units including earthflows. The failures mostly tend to occur on the lower topographic altitudes of the catchment. The main reason for this peculiarity is the intense chemical weathering observed on the lower altitudes of the region. On the other hand, the mean slope gradient value for the catchment area is calculated as $26^{\circ}$. The maximum slope gradient is observed as $61^{\circ}$ in the catchment area while the parameter varies between the values of $3^{\circ}$ and $41^{\circ}$ on the terrain units including earthflows. Additionally, considering the descriptive statistics, it could be assessed that the earthflows observed in the catchment area tend to occur on the slopes having profile convex and plan concave slope curvatures. 
Table 1: Descriptive statistics for the conditioning factors.

\begin{tabular}{|c|c|c|c|c|c|}
\hline Parameter & Min. & Max. & Mean & Std. Deviation & Variance \\
\hline \multicolumn{6}{|c|}{ Data } \\
\hline \multicolumn{6}{|c|}{ The catchment area $(N=266,613)$} \\
\hline \multicolumn{6}{|l|}{ Topographic parameters } \\
\hline Topographic altitude (m) & 6.92 & 1212.25 & 357.79 & 202.88 & 41161.71 \\
\hline Slope gradient $\left(^{\circ}\right)$ & 0.00 & 60.81 & 25.47 & 9.76 & 95.24 \\
\hline Profile slope curvature $\left(100^{-1} \mathrm{~m}\right)$ & -15.28 & 15.27 & 0.03 & 1.88 & 3.55 \\
\hline Plan slope curvature $\left(100^{-1} \mathrm{~m}\right)$ & -13.41 & 13.58 & 0.03 & 1.64 & 2.69 \\
\hline \multicolumn{6}{|l|}{ Hydrotopographic parameters } \\
\hline Topographic wetness index & 4.53 & 20.51 & 5.63 & 0.64 & 0.41 \\
\hline Stream power index & 0.00 & 11.97 & 1.22 & 1.30 & 1.68 \\
\hline Sediment transport capacity index & 0.00 & 611.52 & 6.46 & 9.53 & 90.84 \\
\hline Distance to drainage (m) & 0.00 & 546.08 & 85.44 & 69.03 & 4765.66 \\
\hline Drainage density $\left(\mathrm{km}-{ }^{1}\right)$ & 0.00 & 8.32 & 3.71 & 1.47 & 2.16 \\
\hline \multicolumn{6}{|l|}{ Environmental factors } \\
\hline Distance to roads $(\mathrm{m})$ & 0.00 & 728.33 & 123.46 & 122.16 & 14922.51 \\
\hline Road density $\left(\mathrm{km}^{-1}\right)$ & 0.00 & 9.61 & 3.45 & 2.06 & 4.23 \\
\hline Building density $\left(\mathrm{km}^{-2}\right)$ & 0.00 & 170.70 & 38.89 & 31.98 & 1023.01 \\
\hline Norm. difference vegetation index & -0.28 & 0.73 & 0.54 & 0.14 & 0.02 \\
\hline \multicolumn{6}{|c|}{ The earthflows $(N=101)$} \\
\hline \multicolumn{6}{|l|}{ Topographic parameters } \\
\hline Topographic altitude (m) & 78.08 & 449.56 & 261.87 & 78.22 & 6117.68 \\
\hline Slope gradient $\left(^{\circ}\right)$ & 3.35 & 41.33 & 24.28 & 7.72 & 59.65 \\
\hline Profile slope curvature $\left(100^{-1} \mathrm{~m}\right)$ & -4.21 & 4.59 & 0.18 & 1.47 & 2.17 \\
\hline Plan slope curvature $\left(100^{-1} \mathrm{~m}\right)$ & -5.24 & 5.54 & -0.57 & 1.55 & 2.39 \\
\hline \multicolumn{6}{|l|}{ Hydrotopographic parameters } \\
\hline Topographic wetness index & 5.06 & 6.65 & 5.52 & 0.29 & 0.08 \\
\hline Stream power index & 0.00 & 4.24 & 1.37 & 0.94 & 0.88 \\
\hline Sediment transport capacity index & 0.00 & 14.53 & 6.21 & 3.74 & 14.03 \\
\hline Distance to drainage $(\mathrm{m})$ & 0.48 & 314.56 & 110.22 & 62.41 & 3894.78 \\
\hline Drainage density $\left(\mathrm{km}^{-1}\right)$ & 4.32 & 6.60 & 3.54 & 1.33 & 1.76 \\
\hline \multicolumn{6}{|l|}{ Environmental factors } \\
\hline Distance to roads $(\mathrm{m})$ & 2.90 & 246.86 & 70.11 & 52.25 & 2729.69 \\
\hline Road density $\left(\mathrm{km}^{-1}\right)$ & 0.64 & 9.46 & 4.79 & 1.94 & 3.78 \\
\hline Building density $\left(\mathrm{km}^{-2}\right)$ & 12.81 & 161.25 & 62.39 & 30.04 & 902.44 \\
\hline Norm. difference vegetation index & 0.16 & 0.68 & 0.55 & 0.10 & 0.01 \\
\hline
\end{tabular}

In order to investigate the topographic hydrology in the Catakli catchment area, the parameters topographic wetness index, stream power index, sediment transport capacity index, distance to drainage $(\mathrm{m})$, and drainage density $\left(\mathrm{km}^{-1}\right)$ were considered (Table 1$)$. Topographic wetness index values in the catchment area vary between 4.53 and 20.51. This range is obtained as 5.06 and 6.65 on the terrain units including earthflows. Additionally, the mean value of the parameter is calculated as 5.52 on these terrain units. Similar distribution characteristics are observed for the parameters stream power index and sediment 
transport capacity index as well. The drainage channels having relatively wide alluvial floors in the catchment area constitute the main reason for this peculiarity. Even though the hydrotopographic parameters vary in wide ranges, the earthflows occur at the values of these parameters distributed in narrow intervals around the mean values of the catchment area. These narrow variation intervals represent the hydrotopographic parameter conditions contributing to supply necessary amount of soil water content at the time of failure. The distance to drainage and the drainage density values on the terrain units including earthflows vary between the values $0 \mathrm{~m}$ and $315 \mathrm{~m}$, and $4.32 \mathrm{~km}^{-1}$ and $6.60 \mathrm{~km}^{-1}$, respectively. Considering the descriptive statistics for the parameters in the catchment area, it could be interpreted that the earthflows tend to occur on the terrain units having higher drainage densities and being close to drainages.

The parameters distance to roads, road density, building density, and normalized difference vegetation index were evaluated as the environmental conditioning factors in the study. The descriptive statistics for these factors are also provided in Table 1 . The mean values of the distance to roads and road density are obtained as $124 \mathrm{~m}$ and $3.45 \mathrm{~km}^{-1}$, and $70 \mathrm{~m}$ and $4.79 \mathrm{~km}^{-1}$ in the catchment area and on the terrain units including earthflows, respectively. Additionally, the mean value of the parameter building density approximately increases twice on the terrain units including earthflows. Considering these descriptive evaluations, the effects of the roads and the buildings to the occurrence of the earthflows in the catchment area could be evidently realized. In order to evaluate the vegetation in the catchment area, the parameter normalized difference vegetation index was also considered. For the purpose, Terra/ASTER satellite data dated 12.04.2004 was implemented in MicroImages TNTmips 6.9 environment. The values of the parameter vary between -0.28 and 0.73 in the catchment area. The mean value for this index parameter is calculated as 0.55 on the terrain units including earthflows. Therefore, it could be concluded that the earthflows tend to occur on the terrain units having relatively higher values of the parameter in the catchment area.

\section{Probability of Spatial Occurrence}

To evaluate the probability of spatial occurrence of the earthflows in the catchment area, a multivariate statistical analysis in the form of logistic regression was implemented. In recent literature, many applications of the logistic regression technique to assess landslide susceptibility, the probability of spatial occurrence, have been published [19-33]. The fundamental principle of the logistic regression technique is based on the analysis of a problem in which a result measured with dichotomous variables (such as 0 and 1 , or true and false) is determined from one or more independent factors [34]. Generally, logistic regression involves fitting the dependent variable using an equation in the following form (4.1).

$$
Y=\operatorname{logit}(P)=\ln \left(\frac{P}{1-P}\right)=\beta_{0}+\beta_{1} x_{1}+\cdots+\beta_{n} x_{n}
$$

where $P$ is the probability that the dependent variable $(Y)$ is $1, P /(1-P)$ is the so-called odds or likelihood ratio, $\beta_{0}$ is the intercept, and $\beta_{1}, \ldots, \beta_{n}$ are the coefficients that measure the contribution of independent factors $\left(x_{1}, \ldots, x_{n}\right)$ to the variations in $Y$. In the present study, the dependent variable is defined as the presence or nonpresence of the earthflow while the independent variables are the conditioning factors which have been already discussed in the previous section: 9 topographic and hydrotopographic parameters, 4 environmental 
factors in continuous format, and 2 parameters in binary format defining the geologic variables-residual soil decomposing from Tertiary aged undifferentiated volcanic complex and alluvium filling up the alluvial valleys in the catchment area. As mentioned, the main characteristics of the earthflows observed in the catchment area are small-sized and shortlived. For this reason, it is highly challenging to define the areal distribution of these failures on the maps in medium scale. Therefore, it becomes very difficult to define the representative presence data in the terrain units-the grid cells having a spatial resolution of $10 \mathrm{~m} \times 10 \mathrm{~m}$ $\left(100 \mathrm{~m}^{2}\right)$. To overcome this limitation, a new sampling circle approach to define the presence data for the earthflows in medium scale was proposed by Nefeslioglu [13]. In the present study, sampling circle approach introduced by the researcher was considered to define the presence data for the earthflows in the catchment area. However, since there is no necessary amount of data measured in the field to calculate the mean areal distribution of the failures, the equation proposed by Nefeslioglu [13] to determine the appropriate radius value for the sampling circle could not be evaluated. Instead, in the present study, applying a sensitive approach 3 different models were constructed for 3 different samplings depending on the increment of the radius of the sampling circle: (i) the closest grid cell $(N=101$, the number of the presence data), (ii) $r=10 \mathrm{~m}(N=312)$, and (iii) $r=12.5 \mathrm{~m}(N=499)$. The number of the samples with respect to different data sets evaluated in the training and testing stages during the model construction are given in Table 2. The model parameters: confidence intervals, threshold values for the iterations, classification cut off values, and maximum iterations were set to $95 \%, 0.1,0.5$, and 12 , respectively. Stepwise maximum likelihood estimation was implemented to determine the consequent $\beta$ coefficients of the logistic regression equations (Table 3). Performance evaluations of the models with respect to different data sets are provided in Table 2 as well. Since the values of the performance statistics are relatively close to each other, the generalization capacities of the models constructed using different data sets could be interpreted as high. Additionally, when considering the statistics obtained during the independent testing stages, the highest prediction capacity was acquired for the sampling $r=10 \mathrm{~m}(N=312)$. As a consequence, the model constructed using the sampling $r=10 \mathrm{~m}$ $(N=312)$ was evaluated as the resultant earthflow model defining the probability of spatial occurrence for the Catakli catchment area in the present study (4.2).

$$
\ln \left(\frac{P}{1-P}\right)=5.425-0.004 x_{1}-0.373 x_{2}-0.948 x_{3}-0.067 x_{4}+0.005 x_{5}+0.021 x_{6}
$$

where $P$ is the probability of spatial occurrence, $x_{1}$ is the topographic altitude $(\mathrm{m}), x_{2}$ is the plan slope curvature $\left(100^{-1} \mathrm{~m}\right), x_{3}$ is the topographic wetness index, $x_{4}$ is the sediment transport capacity index, $x_{5}$ is the distance to drainage $(\mathrm{m})$, and $x_{6}$ is the building density $\left(\mathrm{km}^{-2}\right)$.

\section{Probability of Temporal Occurrence}

There are different landslide hazards - the probability of temporal occurrence evaluation methods published in the recent literature [35-52]. In general, these methods could be classified under two main headings such as (i) inventory-based techniques and (ii) applications based on the responsible triggering factor [13]. Most of these studies were collected and discussed in detail by Corominas and Moya [53]. Considering different types of applications, it could be evidently realized that, there is still no standardized procedure 
Table 2: Performance evaluations for the earthflow models defining the probability of spatial occurrence with respect to different data sets.

\begin{tabular}{|c|c|c|c|c|c|c|c|}
\hline \multirow[t]{2}{*}{ Data } & \multicolumn{3}{|c|}{$\begin{array}{l}\text { The number of samples } \\
\text { Training }\end{array}$} & \multicolumn{2}{|c|}{$\begin{array}{l}\text { Correct classification \% } \\
\text { for presence }(1)\end{array}$} & \multirow[t]{2}{*}{$\begin{array}{l}\text { RMSE* for } \\
\text { testing }\end{array}$} & \multirow[t]{2}{*}{$\begin{array}{l}\text { Area under } \\
\text { ROC }^{* *} \text { curve } \\
(\mathrm{AUC})\end{array}$} \\
\hline & Presence (1) & Non-presence $(0)$ & Testing & Training & Testing & & \\
\hline $\begin{array}{l}\text { The closest } \\
\text { grid cell } \\
(N=101)\end{array}$ & 91 & 91 & 10 & 71.4 & 60.0 & 0.431 & 0.756 \\
\hline $\begin{array}{l}r=10 \mathrm{~m} \\
(N=312)\end{array}$ & 281 & 281 & 31 & 77.6 & 77.4 & 0.390 & 0.771 \\
\hline $\begin{array}{l}r=12.5 \mathrm{~m} \\
(N=499)\end{array}$ & 449 & 449 & 50 & 75.1 & 72.1 & 0.437 & 0.772 \\
\hline
\end{tabular}

${ }^{*}$ RMSE; Root Mean Square Error.

${ }^{* *}$ ROC; Receiver Operating Characteristics.

to assess not only landslide hazard but also landslide susceptibility and landslide risk. According to Corominas and Moya [53], the main reasons for this peculiarity are given as follows; (i) the needs of the user, (ii) the goal of the assessment, (iii) the scale of the work, (iv) quality of the data, and (v) time and funding available. In the present study, the probability of temporal occurrence for the earthflows observed in the catchment area was evaluated based on the responsible triggering factor. The triggering factor of these failures is short-lived heavy rainfalls. The earthflows evaluated in this study were mostly triggered by the meteorological event happened on July 23rd in 2002. The daily rainfall was measured as $107.5 \mathrm{~mm}$ on that day at the Pazar Meteorological Station-the nearest meteorological station to the catchment area. Another extreme meteorological event occurred in the region happened on August 8th in 1995. In this case, the daily rainfall was measured as $146.7 \mathrm{~mm}$ at the same station. Nefeslioglu [13] mentioned that many earthflows were also triggered by this extreme meteorological event in the region. However, since most of the failures in the catchment area were triggered by the event happened on July 23rd in 2002 and the probability of temporal occurrence for the event happened in 2002 is obviously higher than the event happened in 1995, the critical rainfall threshold was selected as the daily rainfall measured on July 23rd in 2002. Therefore, the assumption is that necessary amount of soil water content to trigger the earthflows in the catchment area was provided by $107.5 \mathrm{~mm}$ daily rainfall received on July 23rd in 2002 . To determine the behavior of the critical rainfall threshold in time in the region, the Gumbel probability distribution model [54] was assessed. The model is based on the distribution of the largest or the smallest values observed in repeated samples. The probability of occurrence of a magnitude equal to or greater than any $x$ value could be computed by using the equation given below (5.1).

$$
P=1-e^{-e^{-y}}
$$

where $y$ is the reduced variate of the distribution. In order to construct the distribution model, the daily rainfall data measured in 33 years between 1975 and 2007 at the Pazar Meteorological Station was evaluated (Figure 5). It should be paid attention that the values of the probability of spatial occurrence of the earthflows and the probability of temporal occurrence of the critical rainfall threshold are completely independent. Hence, the product of the values of the probability of temporal occurrence of the critical rainfall threshold and 
Table 3: Resultant $\beta$ coefficients and test statistics for the variables in the model equations with respect to different data sets.

\begin{tabular}{|c|c|c|c|c|c|c|c|}
\hline Data & Parameter & $\beta$ & Std. error & Wald & $\begin{array}{c}\text { Degree of } \\
\text { freedom }\end{array}$ & Sig. & $\operatorname{Exp}(\beta)$ \\
\hline \multirow{5}{*}{$\begin{array}{l}\text { The closest grid } \\
\text { cell }(N=101)\end{array}$} & $\begin{array}{l}\text { Plan slope curvature } \\
\left(100^{-1} \mathrm{~m}\right)\end{array}$ & -0.256 & 0.104 & 6.074 & 1 & 0.014 & 0.774 \\
\hline & $\begin{array}{l}\text { Topographic wetness } \\
\text { index }\end{array}$ & -0.767 & 0.366 & 4.405 & 1 & 0.036 & 0.464 \\
\hline & Distance to roads $(\mathrm{m})$ & -0.005 & 0.002 & 4.263 & 1 & 0.039 & 0.995 \\
\hline & $\begin{array}{l}\text { Building density } \\
\left(\mathrm{km}^{-2}\right)\end{array}$ & 0.019 & 0.006 & 9.896 & 1 & 0.002 & 1.020 \\
\hline & Constant & 3.667 & 2.031 & 3.259 & 1 & 0.071 & 39.122 \\
\hline \multirow{7}{*}{$\begin{array}{l}r=10 \mathrm{~m} \\
(N=312)\end{array}$} & $\begin{array}{l}\text { Topographic altitude } \\
\text { (m) }\end{array}$ & -0.004 & 0.001 & 20.351 & 1 & 0.000 & 0.996 \\
\hline & $\begin{array}{l}\text { Plan slope curvature } \\
\left(100^{-1} \mathrm{~m}\right)\end{array}$ & -0.373 & 0.077 & 23.669 & 1 & 0.000 & 0.689 \\
\hline & $\begin{array}{l}\text { Topographic wetness } \\
\text { index }\end{array}$ & -0.948 & 0.276 & 11.816 & 1 & 0.001 & 0.388 \\
\hline & $\begin{array}{l}\text { Sediment transport } \\
\text { capacity index }\end{array}$ & -0.067 & 0.023 & 8.600 & 1 & 0.003 & 0.935 \\
\hline & $\begin{array}{l}\text { Distance to drainage } \\
(\mathrm{m})\end{array}$ & 0.005 & 0.002 & 8.946 & 1 & 0.003 & 1.005 \\
\hline & $\begin{array}{l}\text { Building density } \\
\left(\mathrm{km}^{-2}\right)\end{array}$ & 0.021 & 0.004 & 28.140 & 1 & 0.000 & 1.022 \\
\hline & Constant & 5.425 & 1.679 & 10.436 & 1 & 0.001 & 227.001 \\
\hline \multirow{9}{*}{$\begin{array}{l}r=12.5 \mathrm{~m} \\
(N=499)\end{array}$} & $\begin{array}{l}\text { Topographic altitude } \\
(\mathrm{m})\end{array}$ & -0.002 & 0.001 & 7.696 & 1 & 0.006 & 0.998 \\
\hline & $\begin{array}{l}\text { Plan slope curvature } \\
\left(100^{-1} \mathrm{~m}\right)\end{array}$ & -0.272 & 0.059 & 21.419 & 1 & 0.000 & 0.762 \\
\hline & $\begin{array}{l}\text { Topographic wetness } \\
\text { index }\end{array}$ & -0.899 & 0.215 & 17.571 & 1 & 0.000 & 0.407 \\
\hline & Stream power index & 0.675 & 0.215 & 9.811 & 1 & 0.002 & 1.964 \\
\hline & $\begin{array}{l}\text { Sediment transport } \\
\text { capacity index }\end{array}$ & -0.177 & 0.046 & 15.030 & 1 & 0.000 & 0.838 \\
\hline & Distance to roads (m) & -0.004 & 0.001 & 12.200 & 1 & 0.000 & 0.996 \\
\hline & $\begin{array}{l}\text { Building density } \\
\left(\mathrm{km}^{-2}\right)\end{array}$ & 0.017 & 0.003 & 29.904 & 1 & 0.000 & 1.017 \\
\hline & Alluvium & -20.937 & 10427.773 & 0.000 & 1 & 0.998 & 0.000 \\
\hline & Constant & 5.286 & 1.249 & 17.917 & 1 & 0.000 & 197.513 \\
\hline
\end{tabular}

the probability of spatial occurrence of the earthflows in each terrain unit provides spatially distributed earthflow hazard in the catchment area. As a consequence, the earthflow hazard maps representing the probability of temporal occurrence of the failures for the critical rainfall threshold value of $107.5 \mathrm{~mm}$ in the Catakli catchment area are given for the return periods of 1, 2, 5, and $>16$ years in Figure 6. Depending on the increment of the return period of the event, areal distributions of the hazard classes having high probabilities on these maps increase gradually. Obviously, the main reason for this gradual variation is the increment of the probability of temporal occurrence of the critical rainfall threshold depending on 


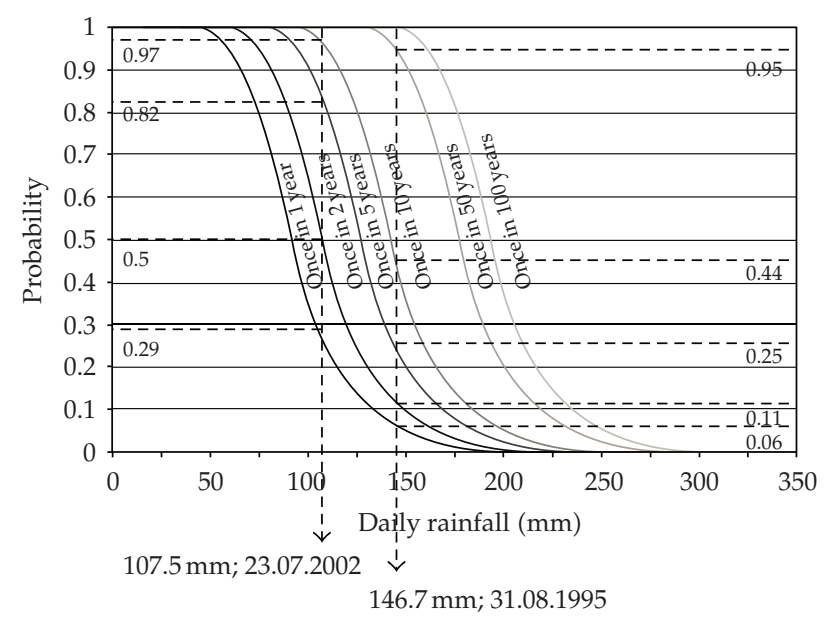

Figure 5: Evaluation of the probability of temporal occurrence for the responsible triggering factor in the catchment.

the increment of the evaluation period. In this case, the probability multiplier coming from the critical rainfall threshold will be equal to 1 after a certain time, and then the probability of temporal occurrence for the earthflows will be equal to the probability of spatial occurrence. This specific relation was also investigated in the present study (Figure 7). The maximum time interval on which the hazard - the critical threshold for the responsible triggering factor-has to be taken into account was defined as the effective return period of the event. Considering the critical threshold value of $107.5 \mathrm{~mm}$ in the catchment area, the effective return period of the event to evaluate the earthflow hazard was determined as 16 years.

\section{Evaluation of the Consequent Risk}

Basic definition for the concept of risk in terms of mass movements could be given as the expected annual loss due to landsliding [55]. There are several mathematical approaches to define this concept in detail in recent literature [5,55-61]. Even though these approaches seem to be different, basically, the equations given by different researchers are based on three main components of the risk concept: (i) hazard, (ii) vulnerability, and (iii) cost. As mentioned previously, although the concept could be defined simply, application of the components in mapping-in medium scale-is highly challenging. However, there are also some attempts to evaluate these main components of the concept in a landslide risk mapping in different scales in recent literature $[40,44,46,48,49,51,52,62,63]$. In the present study, considering the main components of the risk evaluation, a probabilistic approach was introduced to analyze the earthflow risk in medium scale in the Catakli catchment area. For the purpose, some basic concepts such as "Risk Cube", "Risk Plane", and "Risk Vector" were defined. The first component of the concept, hazard, was partitioned into two subcomponents and defined as the probability of spatial occurrence and the probability of temporal occurrence. Additionally, the multiplier vulnerability - the second main component of the risk evaluation-was handled as an independent component of the concept. Therefore, assigning these components onto the principal axes-the probability of the spatial occurrence on the $x$-axis, the probability 


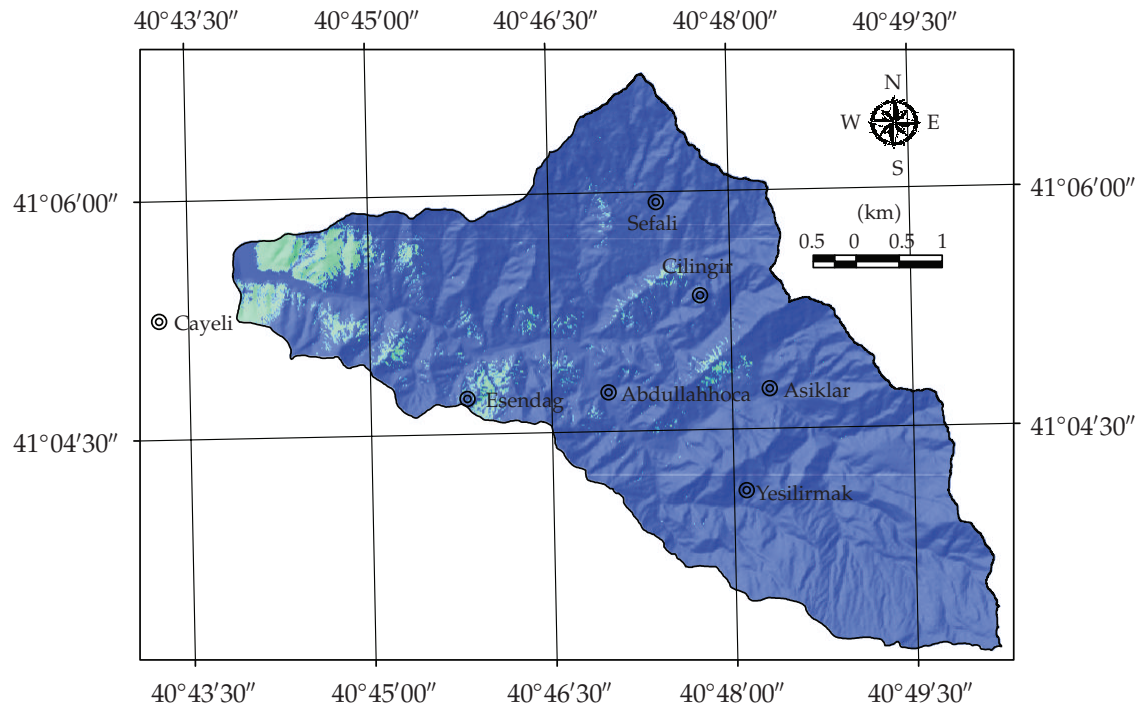

$\square$ Very low $(0-0.25)$

$\square$ Low $(0.25-0.5)$

$\square$ High (0.5-0.75

$\square$ Very high $(0.75-1)$

(a)

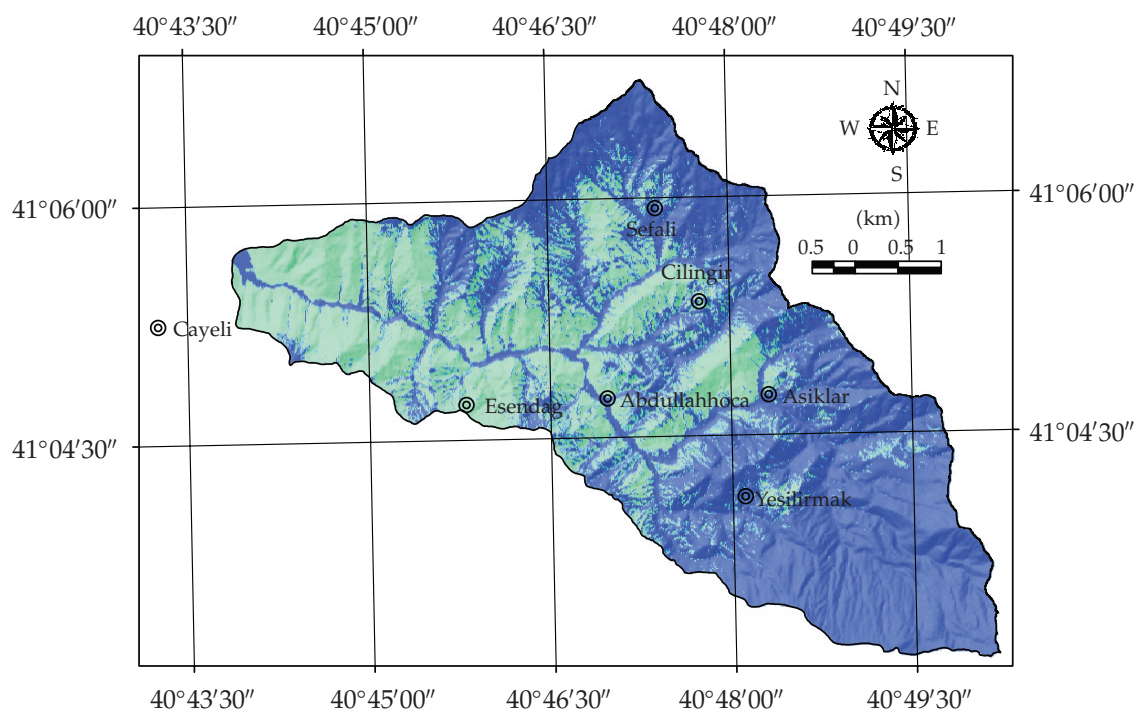

Very low (0-0.25)

$\square$ Low $(0.25-0.5)$

$\square$ High (0.5-0.75)

$\square$ Very high (0.75-1)

(b)

Figure 6: Continued. 


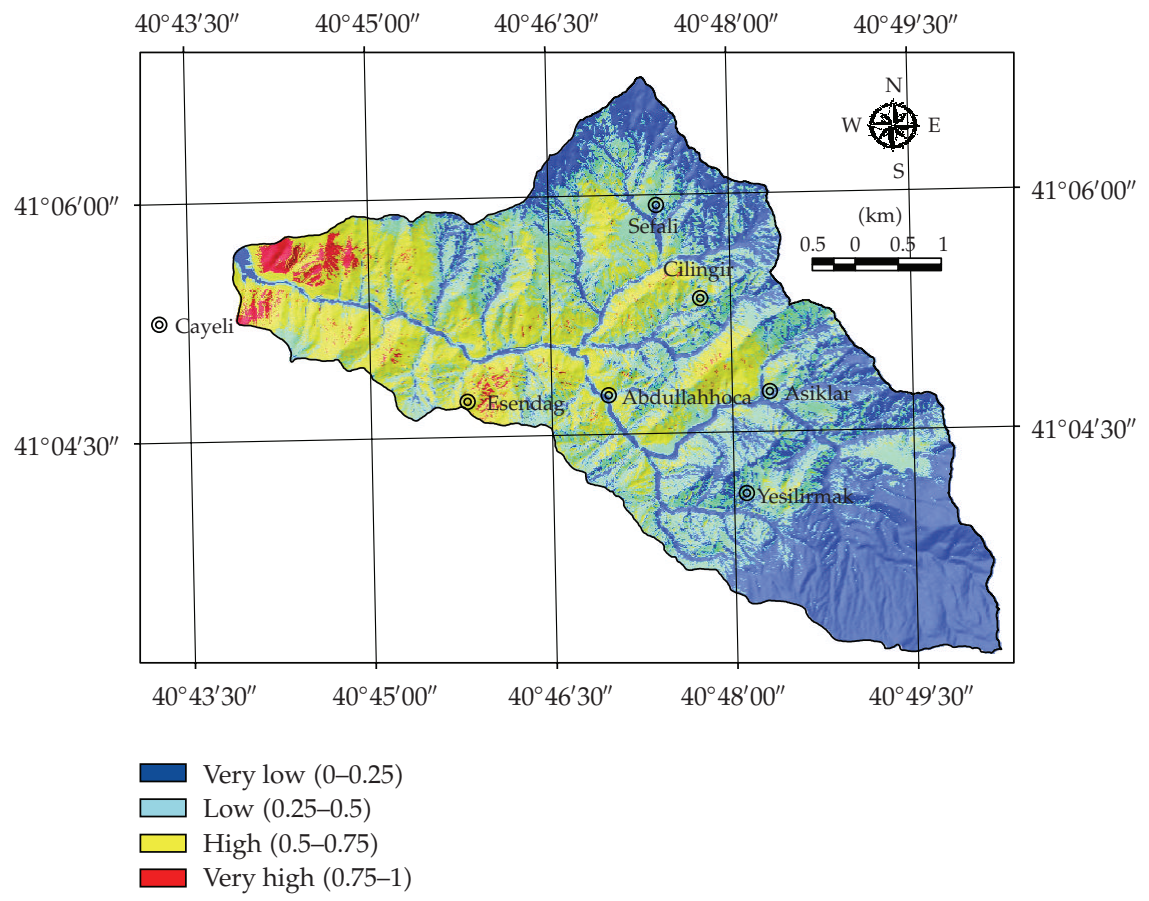

(c)

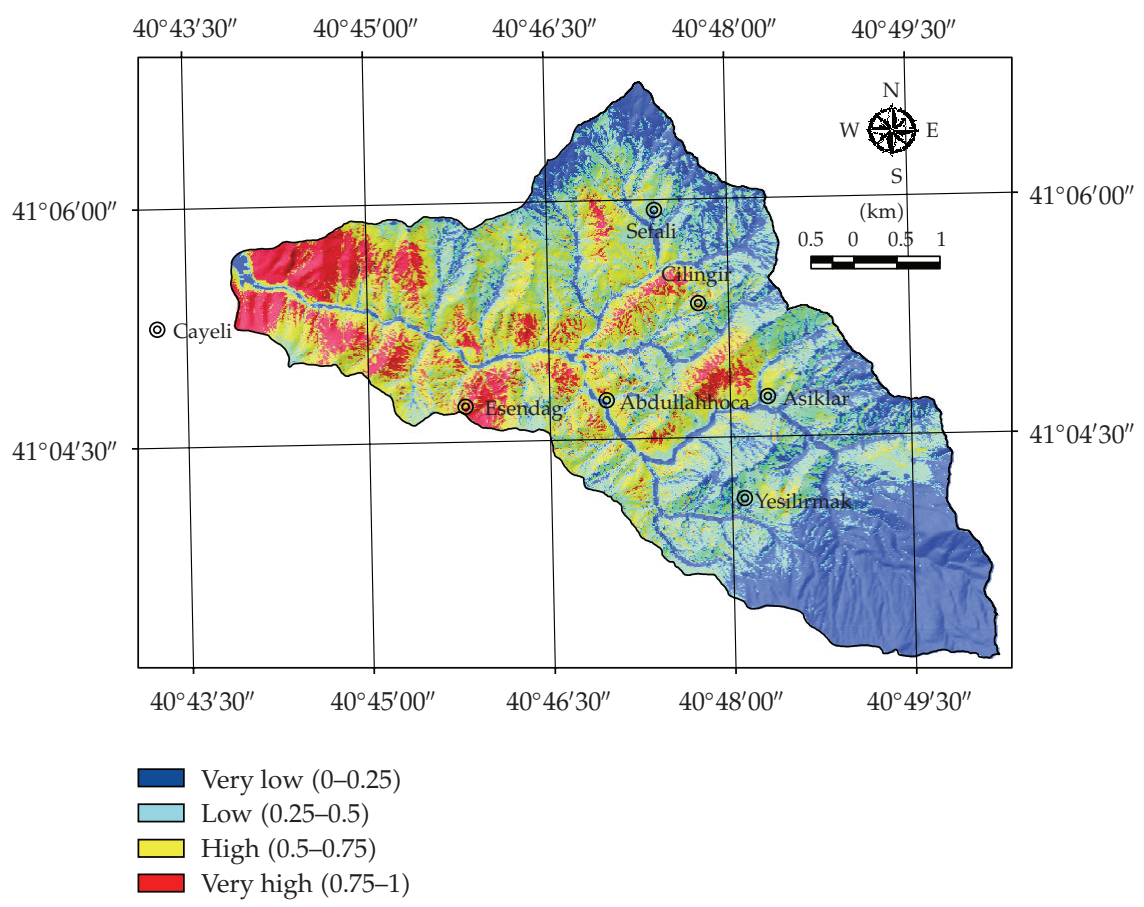

(d)

Figure 6: Earthflow hazard maps of the Catakli catchment area for the return periods of (a) 1 year, (b) 2 years, (c) 5 years, and (d) $>16$ years. 
of the temporal occurrence on the $y$-axis, and the vulnerability on the $z$-axis-a regular hexahedron shape was obtained. This shape was defined as the "Risk Cube" in the present study. The planes and vectors in the risk cube were defined as the "Risk Plane" and "Risk Vector", respectively. Hence, considering the concept of risk cube, the risk equation which is able to be evaluated using each plane and vector as well as all of the cube was written as given in (6.1).

$$
R(P)=\sum_{i=1}^{k}\left[P\left(S_{i}\right) \times P\left(T_{i}\right) \times V_{i}\right] \times C,
$$

where $P\left(S_{i}\right)$ is the probability of spatial occurrence, $P\left(T_{i}\right)$ is the probability of temporal occurrence, $V_{i}$ is the vulnerability, and $C$ is the cost. The second component of the risk evaluation-vulnerability of which the values vary between 0 and 1 -is defined as the measure capable of being damaged by a mass movement having a certain magnitude for the elements at risk [55, 57, 64, 65]. Dai et al. [66] mentioned that assigning of these values for the elements at risk is mostly subjective and usually based on the historical records. One of the most well-known approaches introduced by Leone et al. [64] is the structural vulnerability matrix. In order to develop this matrix for a certain application site, a necessary amount of historical data is required. Unfortunately, this could not be always possible. Additionally, when considering possibly expected future failures, mapping of this concept in medium scale seems to be very difficult. In the present study, to assign the vulnerability values to the terrain units being studied in medium scale a new more robust and more objective equation based on spatial resolution and distance was proposed (6.2).

$$
V_{i}= \begin{cases}1, & d<\frac{h}{2}+m, \\ \frac{(h / 2)+m}{n \times d}, & d \geq \frac{h}{2}+m,\end{cases}
$$

where $d$ is the spatial distance to elements at risk, $h$ is the square root of the spatial resolution, $m$ is the increment constant, and $n$ is the type constant depending on the spatial definition of the element at risk in medium scale; $n=4$ for discrete structures, and $n=2$ for continuous structures. In the proposed equation, if the possibly expected future failure occurs on the terrain unit where the element at risk locates, the predicted vulnerability is assigned to 1. Additionally, depending on the increment of the failure distance to the element at risk, the vulnerability arising from this failure decreases gradually under control of a function of the spatial distance (Figure 8). Since the effective distance to element at risk is also controlled by the magnitude of the event, to represent this effect as an expert opinion, the increment constant $m$ varying between 0 and 1 was implemented in the equation. Depending on the increment of the $m$ value, expected vulnerability values arising from surrounding terrain units increase. In the present study, considering the general characteristics of the failures in the region, the increment constant $\mathrm{m}$ was taken as 0.25 .

The roads in the catchment area were evaluated as the elements at risk-as an example application for the proposed technique in the present study. Obviously, the interruptions happened on transportation due to the earthflows occurred in the region cause not only direct but also indirect consequences in the catchment area. However, in the present study, only the expected economic risks arising from direct consequences were calculated. The roads are constructed using mainly concrete type of pavement in the region. According to the records 


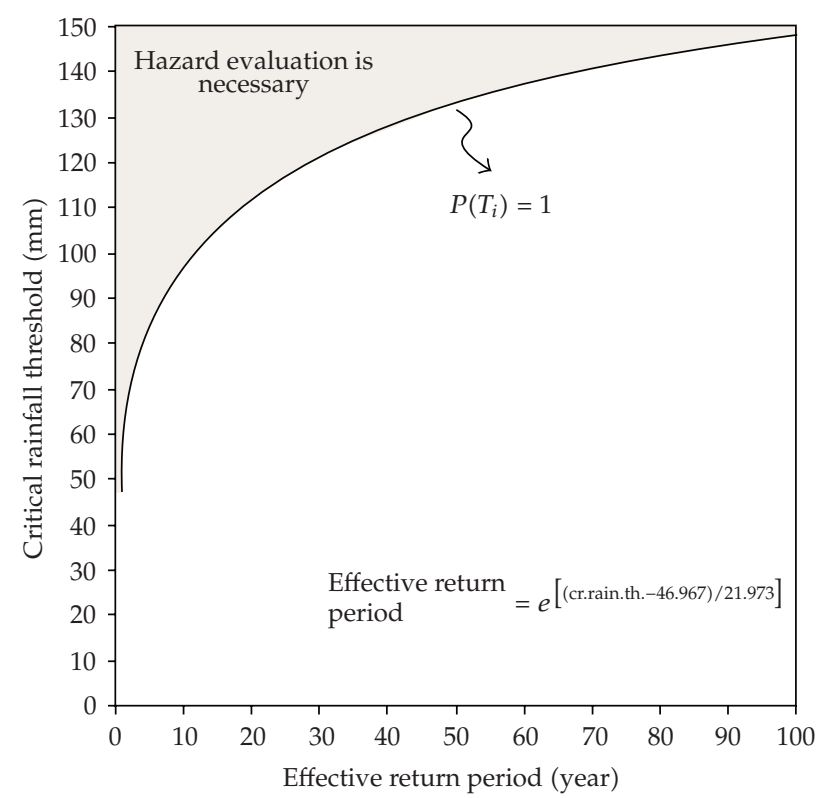

Figure 7: Evaluation of the effective return period for the catchment area.

of the year 2004, the average cost for the concrete road construction is given as approximately $241.3 € / \mathrm{m}$ [67]. In the present study, total length of $103 \mathrm{~km}$ concrete road is represented using 10,271 terrain units in continuous grid structure. Hence, considering the cost assigned for 1 terrain unit $(241.3 € / \mathrm{m} \times 10 \mathrm{~m})$, total cost for the concrete roads in the catchment area is calculated as $24.8 \times 10^{6} €$. As a consequence, the expected risks for the critical situations defined by using different risk vectors and risk planes are given in Figure 9. Additionally, close views from the spatial distributions of the expected risks were also provided in Figure 9. Considering the occurrence of possibly expected future failure on the terrain units including elements at risk - the roads, the risk value for 1 year is calculated as $3.6 \times 10^{6} €$ while that of value is estimated as $4.9 \times 10^{6} €$ for $>16$ years. On the other hand, considering the risks arising from surrounding terrain units on the elements at risk, the risk value for 1 year is calculated as $12.3 \times 10^{6} €$ while that of value is estimated as $16.9 \times 10^{6} €$ for $>16$ years in this case.

\section{Discussions and Conclusions}

In the present study, a probabilistic approach was introduced in order to perform risk analyses in medium scale $(1: 25,000)$ for the rainfall-induced earthflows occurring in the Catakli catchment area (Cayeli, Rize, Turkey). For the purpose of the study, the earthflows mostly triggered by the meteorological event happened on July 23rd in 2002 were evaluated. It is assumed that necessary amount of soil water content was supplied by the daily rainfall $107.5 \mathrm{~mm}$ measured at the Pazar Meteorological Station nearby the catchment area on that day. Obviously, the earthflows might be triggered at different amounts of soil water content depending on the conditioning factors. On the other hand, unfortunately it is not feasible to determine the exact threshold values which will trigger the earthflows on each terrain unit in medium scale. Therefore, the assumption that the minimum amount of soil water 


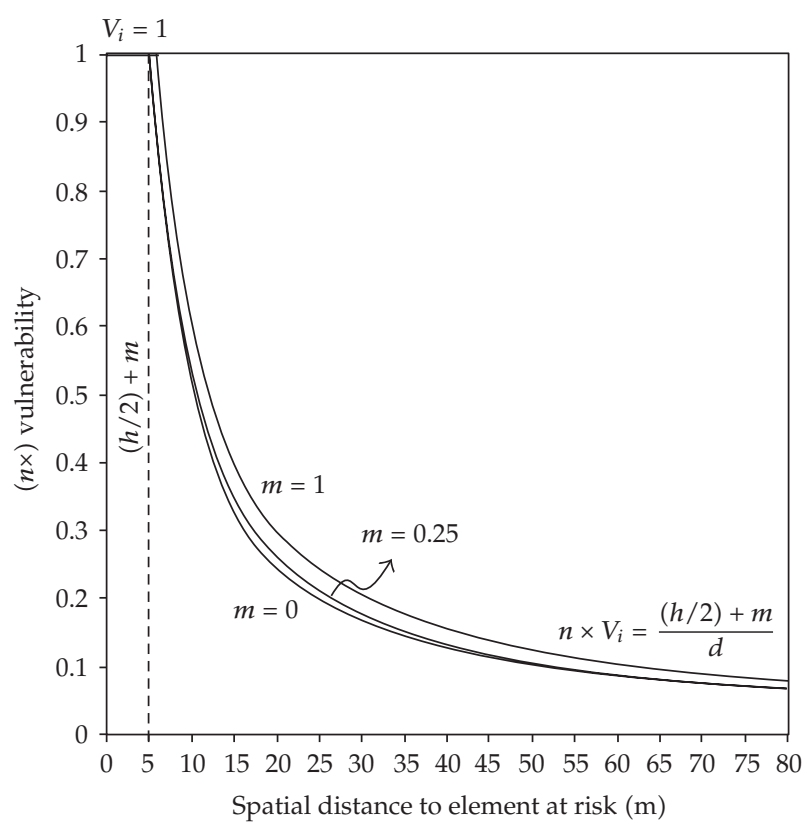

Figure 8: Vulnerability assessment for the elements at risk.

content is provided by the daily rainfall $107.5 \mathrm{~mm}$ to trigger an earthflow in the region enables to map the earthflow hazard in medium scale in the catchment area. Considering the occurrence probability of the critical threshold value in time, a new concept-the effective return period for hazard evaluation - was introduced. In case of the evaluation performed on time interval over the effective return period for the critical threshold value, the probability of spatial occurrence is able to be defined as the probability of temporal occurrence. In the present study, the effective return period for the critical threshold value of $107.5 \mathrm{~mm}$ was determined as 16 years. Hence, as the critical situations, the risk analyses were performed considering the return periods of both 1 year and $>16$ years together. For the purpose, some additional basic concepts such as "Risk Cube", "Risk Plane", and "Risk Vector" were also introduced. The principal axes of a regular hexahedron were defined using the components of the risk equation given in the present study. The component defining the probability of spatial occurrence was represented continuously on the $x$-axis in the cube for each terrain unit in the catchment area. On the other hand, the component defining the probability of temporal occurrence was represented on the $y$-axis in discrete format. This means that each probability value for different return periods will define different planes being independent from each other in the cube. Additionally, in order to assign the vulnerability values to the terrain units in medium scale, a new approach based on a discrete function of the spatial distance to element at risk was proposed in the present study. Considering this discrete function, the vulnerability values were represented continuously on the $z$-axis on the interval $[0,1)$. In this case, the risk values are able to be represented using risk planes. On the other hand, in case the vulnerability is equal to 1 , the risk values are represented as unique risk vectors in the risk cube. Considering the Cartesian grid coordinate system commonly using in medium scaled studies, the terrain units including elements at risk defined by continuous-linear structures are evaluated twice while that of represented by 


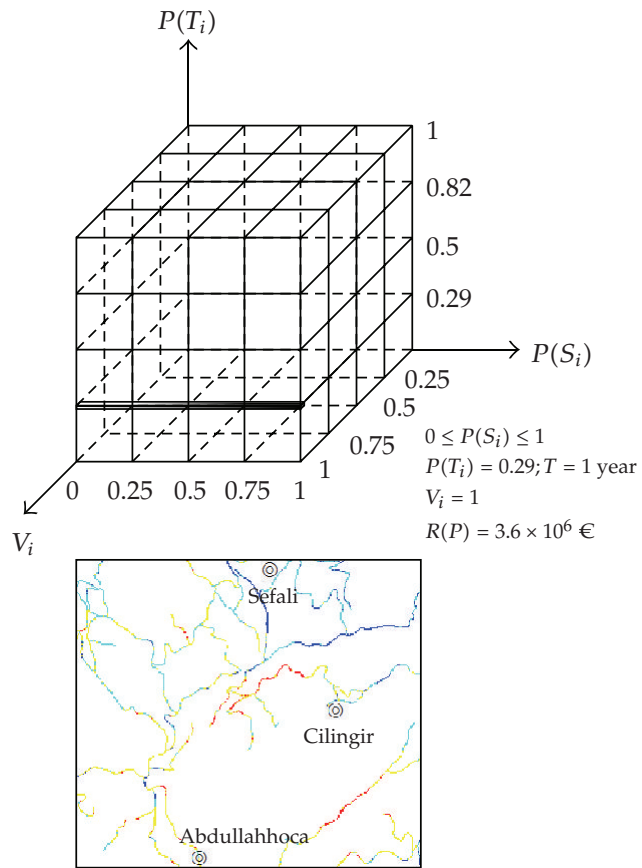

(a)

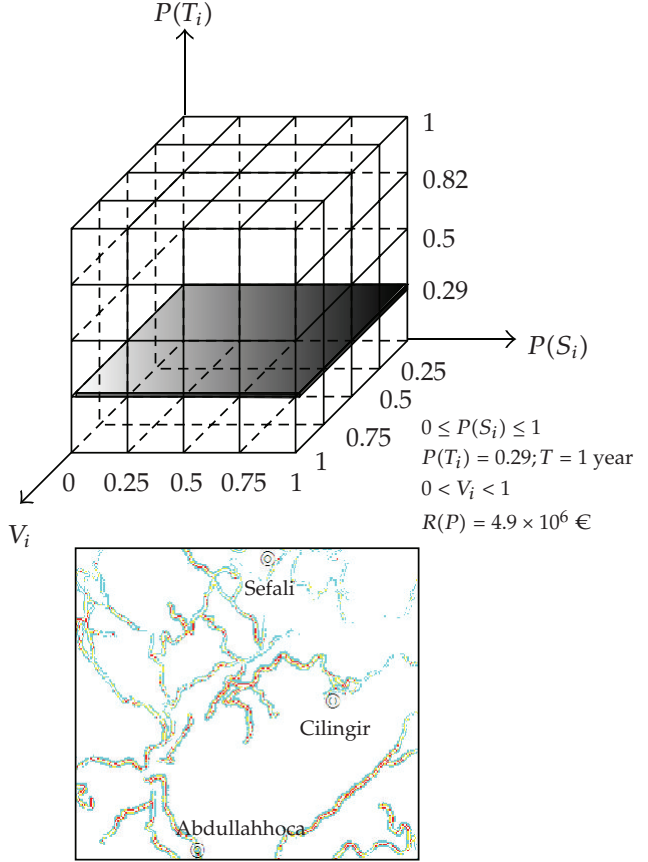

(b)

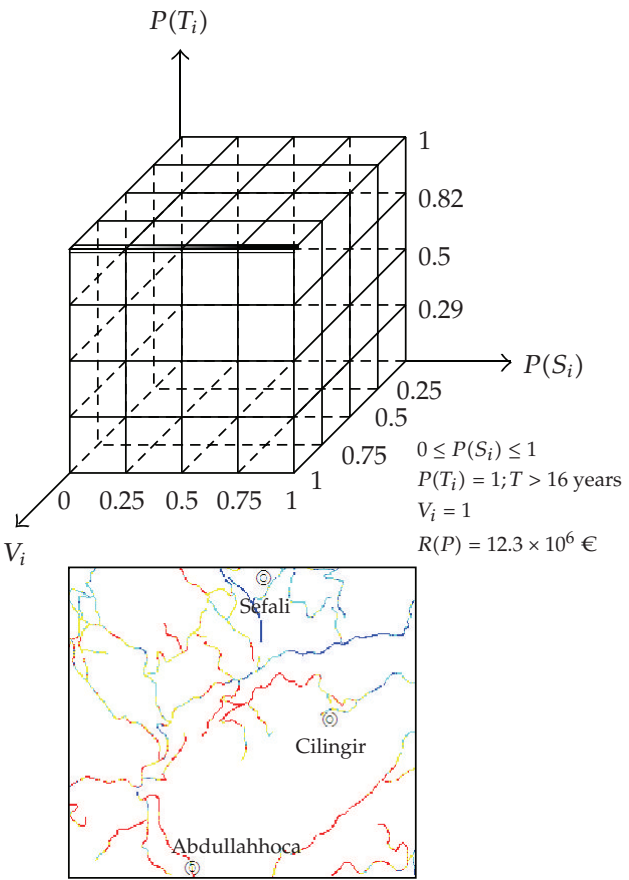

(c)

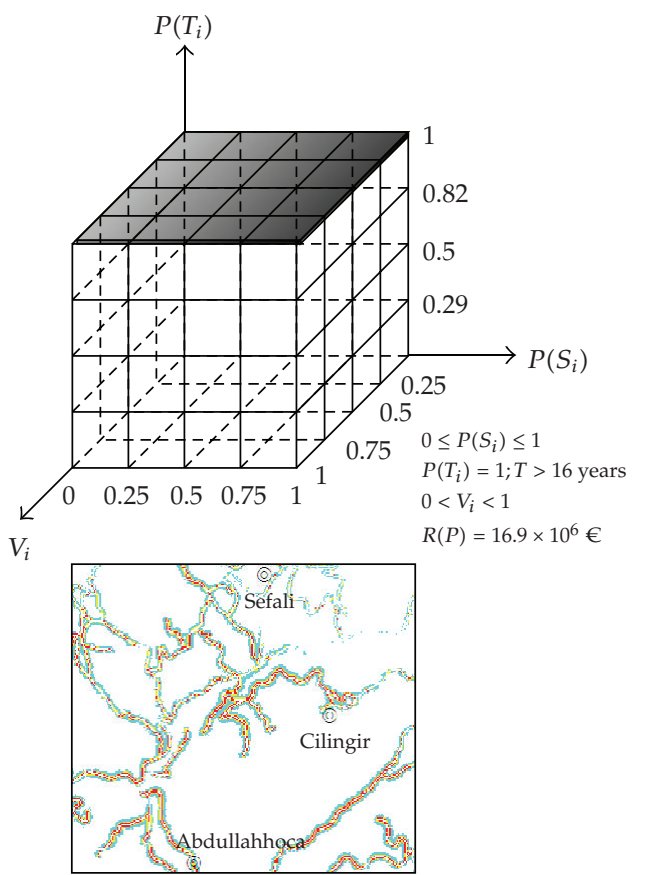

(d)

Figure 9: Expected economic risks on the roads arising from direct consequences in the Catakli catchment area: for 1 year and $>16$ years defined by the risk vectors $V_{i}=1$ and risk planes $0<V_{i}<1$. 
discrete-point structures are assessed four times in one calculation step. Hence, a multiple effect arises in vulnerability evaluations and causes an overestimation in consequent risk results. In order to remove this multiple effect, a type constant $(n)$ defining the representation of the elements at risk in Cartesian grid coordinates system was included in the vulnerability equation. Consequently, considering the vulnerability equation introduced in the present study, the risk values are able to be calculated for the terrain units including elements at risk. Additionally, the risks arising from the surrounding terrain units are able to be evaluated as well.

Since the available data measured at the Pazar Meteorological Station is daily rainfall, a period of 33 years was able to be evaluated during the analyses performed in the study. However, it is well known that the rainfall phenomenon has inherent scaling properties within the specified range of scales [68,69]. Additionally, scaling is also essential for random data analysis [70,71]. On this account, for the future works, the method proposed in the present study could be applied and modified at different sites where the infra-daily rainfall data is available. However, it should be paid attention that the Gumbel probability distribution model might give underestimated results particularly for high return periods at that point [69]. Therefore, for such situations heavy-tailed probability distributions should also be taken into consideration $[69,72]$.

As the final conclusion, the risk assessments performed in medium scale considering the technique proposed in the present study will supply substantial economic contributions to the mitigation planning studies in the region.

\section{Acknowledgments}

This study was supported by the Hacettepe University Scientific Research Unit (Ankara, Turkey) with the project 0701602006 and performed as an individual research under JICA Training and Dialogue Programs Leader's Training Program no. J0900804/ID 0980876. The authors also would like to thank Dr. Tamer Y. Duman for providing the earthflow data.

\section{References}

[1] V. Singhroy, "Remote sensing of landslides," in Landslide Hazard and Risk, T. Glade, M. Anderson, and M. J. Crozier, Eds., pp. 469-492, John Wiley \& Sons, West Sussex, UK, 2005.

[2] ISDR (International Strategy for Disaster Reduction), "Disasters Impact," 2010, http://www.unisdr .org/disaster-statistics/impact-killed.htm.

[3] O. Ergunay, "A perspective of disaster management in Turkey: issues and prospects. Urban settlements and natural disasters," in Proceedings of UIA Region II Workshop, pp. 1-9, 1999.

[4] IUGS (Working Group on Landslides, Committee on Risk Assessment), “Quantitative risk assessment for slopes and landslides-the state of the art," in Landslide Risk Assessment, D. Cruden and R. Fell, Eds., pp. 3-12, A.A. Balkema, Rotterdam, The Netherlands, 1997.

[5] C. J. Van Westen, T. W. J. Van Asch, and R. Soeters, "Landslide hazard and risk zonation-why is it still so difficult?" Bulletin of Engineering Geology and the Environment, vol. 65, no. 2, pp. 167-184, 2005.

[6] L. Cascini, "Applicability of landslide susceptibility and hazard zoning at different scales," Engineering Geology, vol. 102, no. 3-4, pp. 164-177, 2008.

[7] R. Fell, J. Corominas, C. Bonnard, L. Cascini, E. Leroi, and W. Z. Savage, "Guidelines for landslide susceptibility, hazard and risk zoning for land use planning," Engineering Geology, vol. 102, no. 3-4, pp. 85-98, 2008.

[8] R. Fell, J. Corominas, C. Bonnard, L. Cascini, E. Leroi, and W. Z. Savage, "Guidelines for landslide susceptibility, hazard and risk zoning for land-use planning," Engineering Geology, vol. 102, no. 3-4, pp. 99-111, 2008.

[9] DMI, “DMI Genel Mudurlugu,” 2008, http://www.meteoroloji.gov.tr/index.aspx. 
[10] F. Tarhan, "Dogu Karadeniz heyelanlarina genel bir bakis," in 1. Ulusal Heyelan Sempozyumu Bildiriler Kitabi, Trabzon, Turkey, 1991.

[11] T. Can, T. Y. Duman, H. A. Nefeslioglu, S. Durmaz, C. Gokceoglu, and H. Sonmez, "Earthflows in a small catchment from Eastern Black Sea Region (Turkey): conditional (Environmental) factors and susceptibility assessments," in Proceedings of the International Symposium on Latest Natural Disasters: New Challenges for Engineering Geology, Geotechnics and Civil Protection, pp. 82-83, Sofia, Bulgaria, 2005.

[12] S. Dag, F. Bulut, and A. Akgun, "Iki degiskenli istatistiksel analiz yontemi ile Cayeli (Rize) ve cevresindeki heyelanlarin degerlendirilmesi," in TMMOB Jeoloji Muhendisleri Odasi 1. Heyelan Sempozyumu, Bildiriler Kitabi, p. 84, Trabzon, Turkey, 2006.

[13] H. A. Nefeslioglu, Production of earthflow hazard maps (Buyukkoy catchment, Cayeli, Rize), Ph.D. thesis, Hacettepe University, Department of Geological Engineering, 2008.

[14] T. Y. Duman, H. A. Nefeslioglu, T. Can et al., “Turkiye Heyelan Envanteri Haritasi-1/500000 olcekli Trabzon Paftasi," MTA Ozel Yayinlar Serisi, vol. 9, p. 25, 2007.

[15] I. H. Guven, “Trabzon-C30 ve D30 Paftaları," 1/100,000 Olcekli Acinsama Nitelikli Türkiye Jeoloji Haritalari, vol. 59, p. 9, 1998.

[16] B. S. Yilmaz, A. R. Guc, I. Gulibrahimoglu et al., "Rize Ilinin Cevre Jeolojisi,” MTA Raporu, no. 10068, p. 234, 1998 .

[17] P. C. Lambe, "Residual soils," in Landslides: Investigation and Mitigation, A. K. Turner and R. L. Schuster, Eds., vol. 247, pp. 507-524, National Academy Press, Washington, DC, USA, 1996.

[18] E. W. Brand, "Predicting the performance of residual soil slopes," in Proceedings of the 11th International Conference on Soil Mechanics and Foundation Engineering, vol. 5, pp. 2541-2578, San Francisco, Calif, USA, 1988.

[19] P. M. Atkinson and R. Massari, "Generalised linear modelling of susceptibility to landsliding in the central Apennines, Italy," Computers and Geosciences, vol. 24, no. 4, pp. 373-385, 1998.

[20] F. C. Dai, C. F. Lee, J. Li, and Z. W. Xu, "Assessment of landslide susceptibility on the natural terrain of Lantau Island, Hong Kong," Environmental Geology, vol. 40, no. 3, pp. 381-391, 2001.

[21] S. Lee and K. Min, "Statistical analysis of landslide susceptibility at Yongin, Korea," Environmental Geology, vol. 40, no. 9, pp. 1095-1113, 2001.

[22] G. C. Ohlmacher and J. C. Davis, "Using multiple logistic regression and GIS technology to predict landslide hazard in northeast Kansas, USA," Engineering Geology, vol. 69, no. 3-4, pp. 331-343, 2003.

[23] M. L. Süzen and V. Doyuran, "A comparison of the GIS based landslide susceptibility assessment methods: multivariate versus bivariate," Environmental Geology, vol. 45, no. 5, pp. 665-679, 2004.

[24] L. Ayalew and H. Yamagishi, "The application of GIS-based logistic regression for landslide susceptibility mapping in the Kakuda-Yahiko Mountains, Central Japan," Geomorphology, vol. 65, no. 1-2, pp. 15-31, 2005.

[25] T. Can, H. A. Nefeslioglu, C. Gokceoglu, H. Sonmez, and T. Y. Duman, "Susceptibility assessments of shallow earthflows triggered by heavy rainfall at three catchments by logistic regression analyses," Geomorphology, vol. 72, no. 1-4, pp. 250-271, 2005.

[26] T. Y. Duman, T. Can, C. Gokceoglu, H. A. Nefeslioglu, and H. Sonmez, "Application of logistic regression for landslide susceptibility zoning of Cekmece Area, Istanbul, Turkey," Environmental Geology, vol. 51, no. 2, pp. 241-256, 2006.

[27] M. Van Den Eeckhaut, T. Vanwalleghem, J. Poesen, G. Govers, G. Verstraeten, and L. Vandekerckhove, "Prediction of landslide susceptibility using rare events logistic regression: a case-study in the Flemish Ardennes (Belgium)," Geomorphology, vol. 76, no. 3-4, pp. 392-410, 2006.

[28] H. A. Nefeslioglu, T. Y. Duman, and S. Durmaz, "Landslide susceptibility mapping for a part of tectonic Kelkit Valley (Eastern Black Sea region of Turkey)," Geomorphology, vol. 94, no. 3-4, pp. 401418, 2008.

[29] H. A. Nefeslioglu, C. Gokceoglu, and H. Sonmez, "An assessment on the use of logistic regression and artificial neural networks with different sampling strategies for the preparation of landslide susceptibility maps," Engineering Geology, vol. 97, no. 3-4, pp. 171-191, 2008.

[30] T. Gorum, B. Gonencgil, C. Gokceoglu, and H. A. Nefeslioglu, "Implementation of reconstructed geomorphologic units in landslide susceptibility mapping: the Melen Gorge (NW Turkey)," Natural Hazards, vol. 46, no. 3, pp. 323-351, 2008.

[31] I. Yilmaz, "Landslide susceptibility mapping using frequency ratio, logistic regression, artificial neural networks and their comparison: a case study from Kat landslides (Tokat-Turkey)," Computers and Geosciences, vol. 35, no. 6, pp. 1125-1138, 2009. 
[32] B. Pradhan and S. Lee, "Delineation of landslide hazard areas on Penang Island, Malaysia, by using frequency ratio, logistic regression, and artificial neural network models," Environmental Earth Sciences, vol. 60, no. 5, pp. 1037-1054, 2010.

[33] B. Pradhan, "Remote sensing and GIS-based landslide hazard analysis and cross-validation using multivariate logistic regression model on three test areas in Malaysia," Advances in Space Research, vol. 45, no. 10, pp. 1244-1256, 2010.

[34] S. Menard, Applied Logistic Regression Analysis, Sage University Paper Series on Quantitative Applications in Social Sciences, Sage, Thousand Oaks, Calif, USA, 1995.

[35] J. A. Coe, J. A. Michael, R. A. Crovelli, and W. Z. Savage, "Preliminary map showing landslide densities, mean recurrence intervals, and exceedance probabilities as determined from historic records, Seattle, Washington," United States Geological Survey Open File Report, no. 00-303, 2000.

[36] R. A. Crovelli, "Probability models for estimation of number and costs of landslides," United States Geological Survey Open File Report, no. 00-249, 2000.

[37] M. Cardinali, P. Reichenbach, F. Guzzetti et al., "A geomorphological approach to the estimation of landslide hazards and risks in Umbria, Central Italy," Natural Hazards and Earth System Sciences, vol. 2, pp. 57-72, 2002.

[38] R. M. Carrasco, J. Pedraza, J. F. Martin-Duque, M. Matttera, M. A. Sanz, and J. M. Bodoque, "Hazard zoning for landslides connected to torrential floods in the Jerte Valley (Spain) by using GIS techniques," Natural Hazards, vol. 30, no. 3, pp. 361-381, 2003.

[39] J. Corominas, R. Copons, J. M. Vilaplana, J. Altimir, and J. Amigó, "Integrated landslide susceptibility analysis and hazard assessment in the principality of Andorra," Natural Hazards, vol. 30, no. 3, pp. 421-435, 2003.

[40] R. Bell and T. Glade, "Quantitative risk analysis for landslides-examples from Bíldudalur, NWIceland," Natural Hazards and Earth System Science, vol. 4, no. 1, pp. 117-131, 2004.

[41] K. T. Chau, Y. L. Sze, M. K. Fung, W. Y. Wong, E. L. Fong, and L. C. P. Chan, "Landslide hazard analysis for Hong Kong using landslide inventory and GIS," Computers and Geosciences, vol. 30, no. 4, pp. 429-443, 2004.

[42] J. L. Zêzere, E. Reis, R. Garcia et al., "Integration of spatial and temporal data for the definition of different landslide hazard scenarios in the area north of Lisbon (Portugal)," Natural Hazards and Earth System Science, vol. 4, no. 1, pp. 133-146, 2004.

[43] R. L. Baum, J. A. Coe, J. W. Godt et al., “Regional landslide-hazard assessment for Seattle, Washington, USA," Landslides, vol. 2, no. 4, pp. 266-279, 2005.

[44] F. Catani, N. Casagli, L. Ermini, G. Righini, and G. Menduni, "Landslide hazard and risk mapping at catchment scale in the Arno River basin," Landslides, vol. 2, no. 4, pp. 329-342, 2005.

[45] C. F. Chung and A. Fabbri, "Systematic procedures of landslide hazard mapping for risk assessment using spatial prediction models," in Landslide Hazard and Risk, T. Glade, M. Anderson, and M. J. Crozier, Eds., pp. 139-174, John Wiley \& Sons, West Sussex, UK, 2005.

[46] J. Corominas, R. Copons, J. Moya, J. M. Vilaplana, J. Altimir, and J. Amigó, "Quantitative assessment of the residual risk in a rockfall protected area," Landslides, vol. 2, no. 4, pp. 343-357, 2005.

[47] F. Guzzetti, P. Reichenbach, M. Cardinali, M. Galli, and F. Ardizzone, "Probabilistic landslide hazard assessment at the basin scale," Geomorphology, vol. 72, no. 1-4, pp. 272-299, 2005.

[48] O. Lateltin, C. Haemmig, H. Raetzo, and C. Bonnard, "Landslide risk management in Switzerland," Landslides, vol. 2, no. 4, pp. 313-320, 2005.

[49] J. Remondo, J. Bonachea, and A. Cendrero, "A statistical approach to landslide risk modelling at basin scale: from landslide susceptibility to quantitative risk assessment," Landslides, vol. 2, no. 4, pp. 321-328, 2005.

[50] Y. Hong, R. Alder, and G. Huffman, "Evaluation of the potential of NASA multi-satellite precipitation analysis in global landslide hazard assessment," Geophysical Research Letters, vol. 33, no. 22, Article ID L22402, 2006.

[51] F. Nadim, O. Kjekstad, P. Peduzzi, C. Herold, and C. Jaedicke, "Global landslide and avalanche hotspots," Landslides, vol. 3, no. 2, pp. 159-173, 2006.

[52] R. W. Romeo, M. Floris, and F. Veneri, "Area-scale landslide hazard and risk assessment," Environmental Geology, vol. 51, no. 1, pp. 1-13, 2006.

[53] J. Corominas and J. Moya, "A review of assessing landslide frequency for hazard zoning purposes," Engineering Geology, vol. 102, no. 3-4, pp. 193-213, 2008. 
[54] E. J. Gumbel, Statistics of Extremes, Columbia University Press, New York, NY, USA, 1958.

[55] R. Fell, K. K. S. Ho, S. Lacasse, and E. Leroi, "A framework for landslide risk assessment and management," in Landslide Risk Management, O. Hungr, R. Fell, R. Couture, and E. Eberhardt, Eds., pp. 3-25, A.A. Balkema, Leiden, The Netherlands, 2005.

[56] D. J. Varnes, "Landslide hazard zonation: a review of principles and practice," Natural Hazards, vol. 3, p. 63, 1984.

[57] R. Fell, "Landslide risk assessment and acceptable risk," Canadian Geotechnical Journal, vol. 31, no. 2, pp. 261-272, 1994.

[58] E. Leroi, "Landslide risk mapping: problems, limitations and developments," in Landslide Risk Assessment, D. Cruden and R. Fell, Eds., pp. 239-250, A.A. Balkema, Rotterdam, The Netherlands, 1997.

[59] H. H. Einstein, "Landslide risk-Systematic approaches to assessment and management," in Landslide Risk Assessment, D. Cruden and R. Fell, Eds., pp. 25-50, A.A. Balkema, Rotterdam, The Netherlands, 1997.

[60] M. J. Croizer and T. Glade, "Landslide hazard and risk: issue, concepts and approach," in Landslide Hazard and Risk, T. Glade, M. Anderson, and M. J. Crozier, Eds., pp. 1-40, John Wiley \& Sons, West Sussex, UK, 2005.

[61] Australian Geomechanics Society, "Landslide risk management concepts and guidelines," Australian Geomechanics, vol. 35, pp. 42-49, 2000.

[62] K. J. Shou and Y. L. Chen, "Spatial risk analysis of Li-shan landslide in Taiwan," Engineering Geology, vol. 80, no. 3-4, pp. 199-213, 2005.

[63] J. L. Zêzere, R. A. C. Garcia, S. C. Oliveira, and E. Reis, "Probabilistic landslide risk analysis considering direct costs in the area north of Lisbon (Portugal)," Geomorphology, vol. 94, no. 3-4, pp. 467-495, 2008.

[64] F. Leone, J. P. Aste, and E. Leroi, "Vulnerability assessment of elements exposed to mass-moving: working toward a better risk perception," in Landslides, K. Senneset, Ed., pp. 263-269, A.A. Balkema, Rotterdam, The Netherlands, 1996.

[65] H. N. Wong, K. K. S. Ho, and Y. C. Chan, "Assessment of consequence of landslides," in Landslide Risk Assessment, D. Cruden and R. Fell, Eds., pp. 111-149, A.A. Balkema, Rotterdam, The Netherlands, 1997.

[66] F. C. Dai, C. F. Lee, and Y. Y. Ngai, "Landslide risk assessment and management: an overview," Engineering Geology, vol. 64, no. 1, pp. 65-87, 2002.

[67] L. Ozler, 2006, http:/ /tr.dexigner.com/tasarim_haberleri/5371.html, (August 2010).

[68] L. Telesca, V. Lapenna, E. Scalcione, and D. Summa, "Searching for time-scaling features in rainfall sequences," Chaos, Solitons and Fractals, vol. 32, no. 1, pp. 35-41, 2007.

[69] D. Ceresetti, G. Molini, and J. D. Creutin, "Scaling properties of heavy rainfall at short duration: a regional analysis," Water Resource Research, vol. 46, no. W09531, p. 12, 2010.

[70] M. Li, "Fractal time series-a tutorial review," Mathematical Problems in Engineering, vol. 2010, Article ID 157264, 26 pages, 2010.

[71] M. Li and W. Zhao, "Representation of a Stochastic Traffic Bound," IEEE Transactions on Parallel and Distributed Systems, vol. 21, no. 9, pp. 1368-1372, 2010.

[72] A. Kalauzi, M. Cukic, H. Millán, S. Bonafoni, and R. Biondi, "Comparison of fractal dimension oscillations and trends of rainfall data from Pastaza Province, Ecuador and Veneto, Italy," Atmospheric Research, vol. 93, no. 4, pp. 673-679, 2009. 


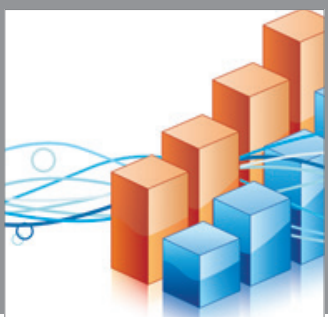

Advances in

Operations Research

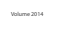

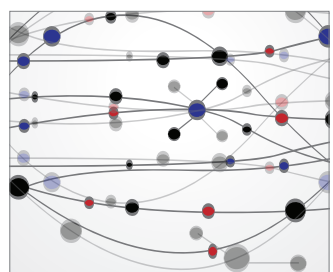

\section{The Scientific} World Journal
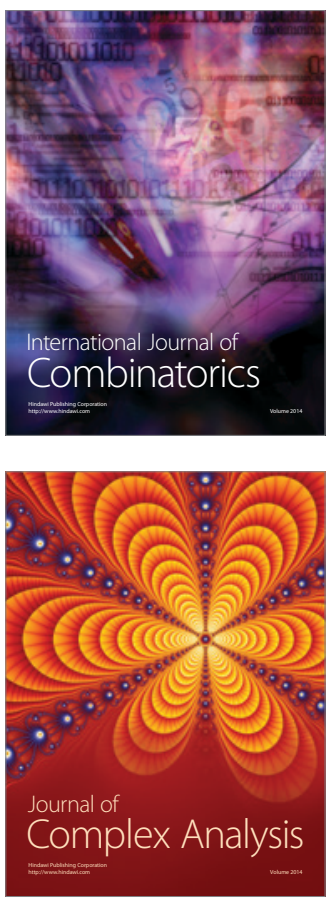

International Journal of

Mathematics and

Mathematical

Sciences
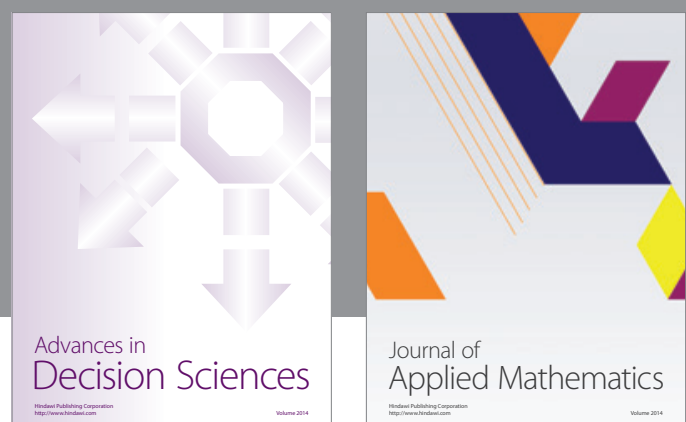

Journal of

Applied Mathematics
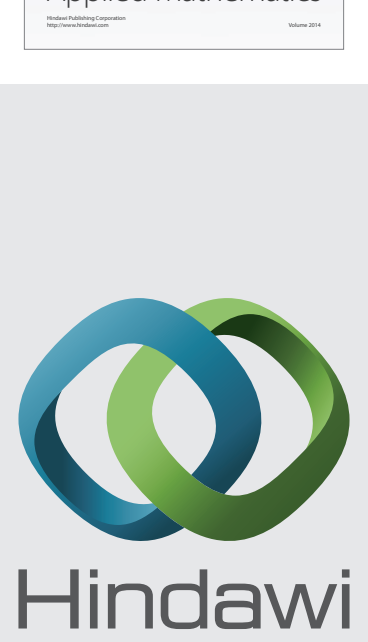

Submit your manuscripts at http://www.hindawi.com
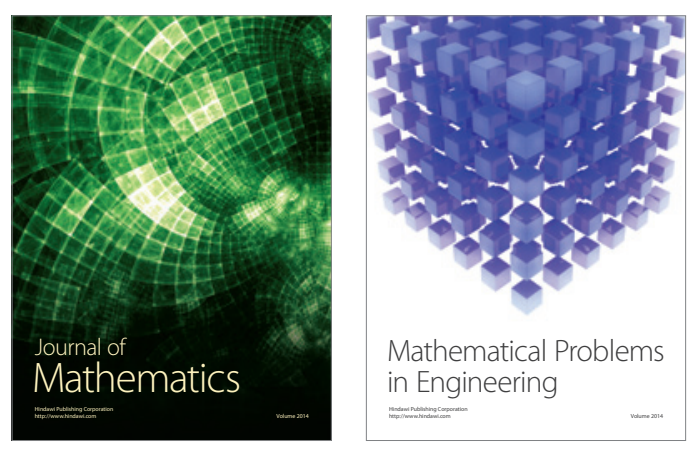

Mathematical Problems in Engineering
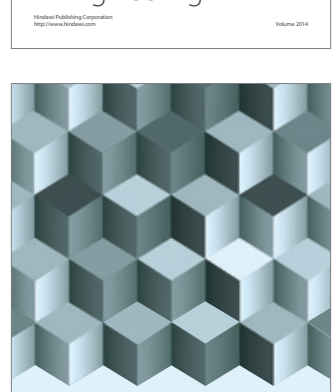

Journal of

Function Spaces
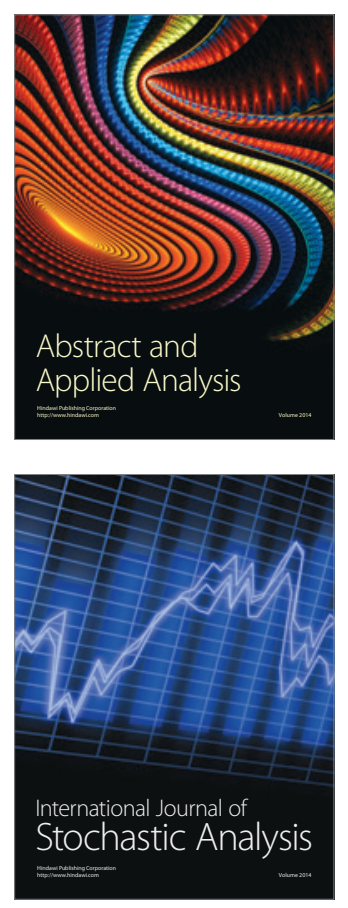

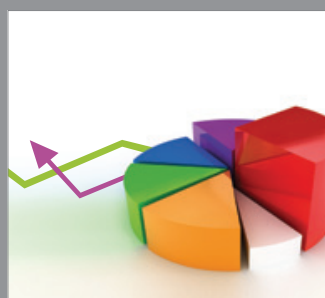

ournal of

Probability and Statistics

Promensencen
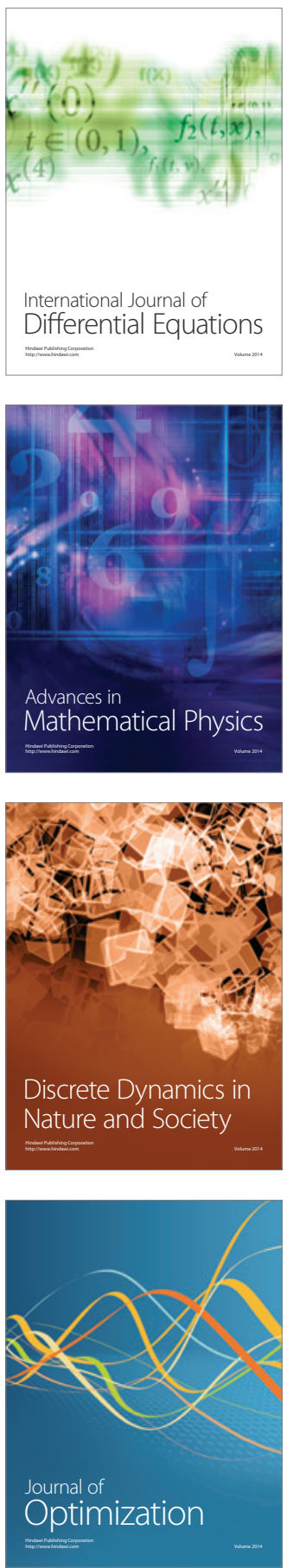